Mawa'izh

Jurnal Dakwah dan Pengembangan Sosial Kemanusiaan

Vol. 8, no. 2 (2017), pp. 293-307.

\title{
Peranan Da'i dalam Mengatasi Problem Dakwah Kontemporer
}

\section{Ikhsan Ghozali}

STAIN Syaikh Abdurrahman Siddik Bangka Belitung, Indonesia

madsanli@yahoo.com

\begin{abstract}
Globalisasi ibarat pisau bermata ganda. Di satu sisi, perkembangan ilmu pengetahuan dan teknologi yang pesat memberi dampak positif bagi perkembangan peradaban manusia. Namun di sisi yang lain, cepatnya perubahan sosial berimbas pada semakin memudarnya nilai-nilai ruhaniyah dan kemanusiaan. Yang muncul adalah kompetisi yang menguatkan gesekan antar-kepentingan --ekonomi, sosial, budaya, politik, agama-- dan mengentalkan rasa saling curiga dan kebencian terhadap orang atau kelompok lain. Akibatnya, terjadi berbagai konflik antarkelompok (SARA/Suku, Agama, Ras, dan Antargolongan), seperti yang terjadi di beberapa wilayah, nasional dan internasional. Maraknya konflik bernuansa SARA ini merupakan problematika dakwah Islamiyah yang perlu menjadi perhatian serius, khususnya bagi para da'i. Untuk itu, para da'i harus mampu "membumikan" dan "mengaktualisasikan" kembali hakikat dan signifikansi dakwah, baik objek dan sasaran, metodologi, manajemen kelembagaan, maupun sumber daya manusia. Selanjutnya, sebagai agent of social change, para da'i mampu membawa perubahan sosial, kehidupan berbangsa dan beragama ke arah yang lebih baik (civil society) serta mewujudkan Islam yang rahmatan lil 'alamin.
\end{abstract}

Keywords; Dakwah Kontemporer, perubahan sosial, civil society.

Received: 11-10-2017; accepted: 14-11-2017; published: 02-12-2017 Citation: M. Ikhsan Ghozali, 'Peranan Da'i dalam Mengatasi Problem Dakwah Kontemporer', Mawa'izh, vol. 8, no. 2 (2017), pp. 293-307. 


\section{A. Pendahuluan}

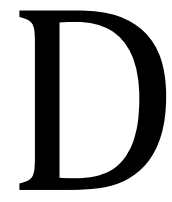

akwah dipahami sebagai bentuk ajakan kepada Islam ${ }^{1}$ merupakan salah satu pondasi dan pilar pokok eksistensi Islam di muka bumi. ${ }^{2}$ Ajaranajaran Islam, baik yang bersifat prinsip autentik dalam kapasitas individu, keluarga, maupun sosial, semuanya menjadi landasan untuk mendekatkan diri kepada Allah SWT, Tuhan yang Maha Kuasa. ${ }^{3}$ Al-Qur'an bahkan menganjurkan adanya komunitas sosial dalam berdakwah, karena peran dan fungsi dakwah yang demikian krusial. ${ }^{4}$

Selama kurun waktu 1998-2000 media massa Indonesia diramaikan oleh berita tentang berbagai konflik yang muncul secara sporadis, baik yang berdimensi agama, etnik, maupun politik. Konflik Maluku yang berawal dari tahun 1997 misalnya, menelan kurang lebih 5.000 korban jiwa, atau kerusuhan KetapangJakarta (22 - 23 Nov 1998) menelan 14 korban jiwa, 22 tempat ibadah rusak dan terbakar. Di negara lain pun tak kalah menariknya, misalnya Perang Bosnia, invasi Amerika ke Afganistan dan Irak dengan alasan memburu teroris dan penegakan demokrasi, ${ }^{5}$ serta perjuangan rakyat Palestina yang tak kunjung selesai.

Menurut Alwi Shihab, konflik antaragama yang banyak terjadi merupakan fenomena yang berumur setua agama-agama itu sendiri. ${ }^{6}$ Bahkan dalam sejarah

${ }^{1}$ Secara teologis, dakwah Islam meliputi dua sasaran yaitu: pertama, masyarakat yang belum mengenal Islam, kedua, masyarakat Islam sendiri. Pada masyarakat yang belum mengenal Islam, dakwah biasanya dipahami sebagai ajakan dan seruan kepada mereka agar mau mempelajari Islam, memeluknya, dan mengamalkan ajaran-ajarannya. Sementara pada masyarakat Muslim sendiri, dakwah dapat diartikan sebagai ajakan atau seruan kepada mereka agar mau melaksanakan ajaranajaran Islam secara kâffah dan mengaplisakannya dalam kehidupan sosial bermasyarakat. Lihat Safrodin Halimi, Etika Dakwah dalam Perspektif Al-Qur'an, Antara Idealitas Qur'ani dan Realitas Sosial, (Semarang: Wali Songo Press, 2008), p. 34. Ditinjau secara etimologi atau bahasa, kata dakwah berasal dari bahasa Arab, yaitu "da'â", artinya mengajak, menyeru, dan memanggil. Warson Munawwir menyebutkan bahwa dakwah artinya adalah memanggil (to call), mengundang (to invite), mengajak (to summon), menyeru (to propose), mendorong (to urge), dan memohon (to pray). Lihat Warson Munawwir, Kamus Al-Munawwir, (Surabaya: Pustaka Progressif, 1997), p. 407.

${ }^{2}$ Safrodin Halimi, Etika Dakwah dalam Perspektif Al-Qur'an, p. 1.

3 Murtadha Husaini, Kode Etik Mubalig Tuntunan Dakwah Secara Islam, (Jakarta: Citra, 2011), p. vi.

${ }^{4}$ Safrodin Halimi, Etika Dakwah dalam Perspektif Al-Qur'an, p. 1.

${ }^{5}$ Lalu Muchsin Efendi dan Faizah, Psikologi Dakwah (Jakarta: Prenada Media, 2006), p. 215.

${ }^{6}$ Alwi Shihab, Islam Inklusif (Bandung: Mizan, 1998), cet. ke-4, hlm. 116. Misalnya Islam, Kristen, dan Yahudi merupakan tiga agama besar yang merupakan agama hanif yang diturunkan kepada Ibrahim (millahIbrâhim). Meskipun demikian, pada kenyataannya menunjukkan bahwa konflik lebih sering terjadi pada tiga komunitas agama ini, bahkan hingga sekarang. 
umat manusia, perang agama merupakan perang terpanjang. ${ }^{7}$ Selama berabadabad, sejarah interaksi antarumat beragama lebih banyak diwarnai oleh kecurigaan dan permusuhan dengan dalih demi mencapai ridha Tuhan. ${ }^{8}$ Sebagai contoh, pola hubungan yang paling dominan antara dua tradisi keimanan, Islam-Kristen, di mana sejak permulaan sejarahnya, Islam dan Kristen memang sudah memiliki suatu bentuk dikotomi pemahaman sehingga berpotensi memunculkan konflik. Maka, tidak mengherankan apabila dalam perkembangannya, permusuhan, kebencian, dan, kecurigaan sepertinya cenderung lebih dikedepankan dibandingkan upaya menjaga bingkai persaudaraan persahabatan dan saling menghormati. ${ }^{9}$

Di sisi lain, transformasi realita tersebut begitu cepat, tak seimbang dibandingkan kehadiran solusi islami yang selalu diharapkan. Ini tentunya semakin memacu kesadaran komunitas Muslim untuk segera terbebas dari nyenyak masa lalunya yang dipenuhi dengan romantisme kedamaian dan kekayaaan. ${ }^{10}$ Ini tentunya memberi pengertian betapa banyak pekerjaan kaum Muslimin yang harus dilakukan.

Dalam tulisan ini, akan dibahas tentang problematika seputar Islam dan globalisasi, dakwah dan perubahan sosial, sebagai bahan introspeksi sekaligus upaya memahami hakikat dan signifikansi dakwah dalam mengarahkan umat Islam kepada suatu tatanan yang lebih mapan.

\section{B. Islam dan Globalisasi}

Umat Islam dan globalisasi11 adalah dua faktor yang senantiasa berkembang, sedangkan umat Islam sendiri adalah bagian yang integral dalam era globalisasi,

${ }^{7}$ Th. Sumarta, "Pluralisme, konflik dan Dialog: Refleksi tentang Hubungan Antar-Agama di Indonesia" dalam Th. Sumarta, dkk., Pluralisme, Konflik dan Pendidikan Agama di Indonesia (Yogyakarta: Interfidei, 2001), p. 80.

8 Alwi Shihab, Islam Inklusif, p. 40.

9 Irawan, "Peran Tasawuf dalam Meredam Konflik Sara pada Era Reformasi di Indonesia" dalam Imam Malik, dkk., Antologi Pemikiran Dakwah Kontemporer (Yogyakarta: Idea Press, 2011), p. 40.

${ }^{10}$ Nurul Badruttamam, Dakwah Kolaboratif Tarmizi Taher (Jakarta: Grafindo Khazanah Ilmu, 2005), p. 23.

${ }^{11}$ Globalisasi berasal dari kata global yang artinya berkenaan dengan keseluruhan, lihat Tim Penyusun. Kamus Besar Bahasa Indonesia (Jakarta: Pusat Bahasa, 2008), hlm. 491. Adapun yang dimaksud dengan globalisasi yaitu proses masuknya ke ruang lingkup dunia. Lihat Tim Penyusun. Kamus Besar Bahasa Indonesia, versi offline dengan mengacu pada data dari KBBI daring (edisi III) dari http://pusatbahasa.diknas.go.id/kbbi/ diakses tanggal 27 Desember 2012. 
maka hubungan di antara keduanya berkembang sebagai hubungan saling mempengaruhi. ${ }^{12}$

Dalam konteks hubungan saling mempengaruhi seperti itu akan memunculkan pertanyaan-pertanyaan: sejauhmana umat Islam dipengaruhi oleh perkembangan global, dan sebaliknya sejauhmana umat Islam mampu mempengaruhi perkembangan global sesuai dengan yang dicita-citakan oleh umat Islam itu sendiri.

Globalisasi bukanlah istilah asing bagi dunia Islam, Al-Qur'an sendiri telah mengajarkan pandangan secara global melalui ajarannya mengenai keberadaan Tuhan sebagai Rabb al-'âlamîn (Tuhan seluruh alam) dan kerasulan Muhammad sebagai rahmat li al-'âlamîn, juga mengenai Al-Qur'an sebagai هداللناس (petunjuk manusia) sejak lima belas abad silam. ${ }^{13}$

Menurut Samsul Munir Amin globalisasi selalu dihubungkan dengan modernisasi dan modernisme. ${ }^{14}$ Namun menurut pakar budaya bahwa ciri khas modernisasi dan manusia modern adalah tingkat berpikir, iptek, dan sikapnya terhadap penggunaan waktu dan perghargaan terhadap karya manusia. Lalu berdasarkan pandangan itu, muncullah penilaian yang membuat klasifikasi kemjuan dan kemunduran. ${ }^{15}$

Namun menurut Islam, maju atau mundur itu diukur berdasarkan nilai-nilai islami, bukan menurut ukuran-ukuran yang lain. Yang dinilai kemajuan menurut Islam mungkin kemunduran menurut yang lain, sebaliknya yang dikatakan kemajuan menurut yang lain mungkin kemunduran menurut Islam.

Globalisasi dapat dipahami dengan makna ganda. Pada satu sisi, globalisasi yang mencakup globalisasi sistem ekonomi, sistem politik, telekomunikasi, dan transportasi memang akhirnya menjadi global. Tetapi pada sisi yang lain, globalisasi dalam bidang kebudayaan, globalisasi budaya dan gaya hidup Barat yang memiliki pretensi-pretensi universal justru mendorong semakin kuatnya resistensi budaya lokal dan regional. Dengan demikian, pada bidang kebudayaan ini terdapat dua

\footnotetext{
${ }^{12}$ Samsul Munir Amin, Rekontruksi Pemikiran Dakwah Islam (Jakarta: Amzah, 2008), p. 164.

${ }^{13}$ Ibid., pp. 164-165.

${ }^{14}$ Ibid., p. 164.

${ }^{15}$ Ibid.
} 
kecenderungan sekaligus; pada satu sisi menguatnya ekspansi budaya global barat, dan pada sisi yang lain meningkatnya kesadaran budaya lokal dan regional nonBarat. ${ }^{16}$

Lebih jauh lagi, globalisasi memang menghasilkan perubahan-perubahan struktur yang sulit dielakkan, baik dalam kehidupan politik maupun ekonomi. Dengan kata lain, struktur-struktur dalam bidang-bidang ini dapat menjadi global dan universal. Akan tetapi, nilai-nilai (values) yang bersumber dari tradisi lokal ataupun agama, dalam banyak hal berkaitan erat dengan realitas lokal dan, karena itu, sulit untuk bisa betul-betul menjadi universal. Di sinilah akhirnya bisa terjadi konflik di antara budaya atau peradaban yang memiliki pretensi-pretensi global, seperti budaya Barat yang ekspansif dengan budaya lokal dan regional yang memiliki nuansa keagamaan tertentu. ${ }^{17}$

\section{Dakwah dan Perubahan Sosial}

Dalam konsep Islam, perubahan sosial (social change) pada sebuah masyarakat merupakan sunnatullah. Perubahan sosial yang terjadi pada masa sekarang sangat kompleks. Perubahan yang terjadi begitu cepat ini, selain menimbulkan hal-hal positif, juga menimbulkan hal yang negatif. Bukan hanya di bidang ekonomi dan politik, tetapi lebih dari itu, ia merambah pada bidang lainnya seperti hukum, budaya, dan moral. ${ }^{18}$

Perubahan sosial merupakan cara untuk mengubah tatanan kondisi masyarakat yang menyimpang, dari yang salah dan buruk menjadi kondisi masyarakat yang terarah, benar, dan baik. ${ }^{19}$ Dalam Al-Qur'an, istilah ini teridentifikasi, antara lain dalam Surat Ar-Ra'd: "Sesungguhnya Allah tidak mengubah suatu kaum hingga mereka mengubah apa yang terdapat dalam diri

16 Azyumardi Azra, Konflik Baru Antar Peradaban; Globalisasi, Radikalisme dan Pluralitas (Jakarta: Raja Grafindo Persada, 2002), p. 15.

17 Ibid.

18 Samsul Munir Amin, Ilmu Dakwah (Jakarta: Amzah, 2009), cet. ke-1, p. 221.

19 Iqram Faldiansyah, "Dakwah dan Lingkungan" dalam Imam Malik, dkk., Antologi Pemikiran Dakwah Kontemporer, (Yogyakarta: Idea Press, 2011), p. 198. Perubahan sosial merupakan perubahan susunan kemasyarakatan dari suatu sistem sosial praindustri ke sistem sosial industrial. Terkadang disejajarkan dengan perubahan dari masyarakat pramodern ke masyarakat modern. Atau, perubahan dari keadaan "negara yang kurang maju" (less developed country) ke keadaan "masyarakat negara yang lebih maju" (more developed country). Lihat Samsul Munir Amin, Ilmu Dakwah, p. 222. 
mereka". ${ }^{20}$ Cara ini telah dipraktikkan oleh Nabi saw. dalam misi dakwahnya. Dalam waktu relatif singkat, yaitu kurang lebih dua puluh tiga tahun, Beliau berhasil melakukuan perubahan sosial yang sangat signifikan terhadap kondisi sosial masyarakat Arab. ${ }^{21}$

Tentang teori perubahan sosial, Tonies mengkontraskan hubungan-hubungan natural dan organis keluarga, desa dan kota kecil (gemeinschaft) dengan kondisi yang "artificial" dan "terisolasi" dari kehidupan kota dan masyarakat industri. Di sini, hubungan-hubungan asli dan natural manusia satu sama lain telah dikesampingkan, dan setiap orang berjuang untuk keuntungannya sendiri dalam suatu semangat kompetisi. ${ }^{22}$

Menguraikan lebih jauh dikotomi Tonnies itu, mengutip dari Samsul Munir Amim, Talcott Parsons mengembangkan suatu teori yang terkenal dengan pattern variables. Menurut teori Parsons ini, perubahan dari masyarakat tradisional ke masyarakat industri dan modern, juga berarti perubahan dari: ${ }^{23}$

1. Affectivity ke affective, yaitu perubahan dan sikap bertindak karena hendak mendapatkan kesenangan segera, ke sikap bertindak dengan kesediaan menunda atau meninggalkan kesenangan jangka pendek. Sasarannya adalah hendak mencapai tujuan-tujuan jangka panjang. Pengaruh langsung perubahan ini bagi proses industrialisasi ialah terbentuknya modal yang diperlukan karena adanya kebiasaan menabung dan investasi akibat ditinggalkannya penggunaan pendapatan untuk maksud-maksud konsumtif.

2. Partikularisme ke universalisme. Industrialisasi cenderung mengikis eksklusivitas partikularistis seperti eksklusivitas rasial, warna kulit, dan keturunan. Partikularisme semacam itu tidak efisien dan membawa ke penyiapan-penyiapan tenaga. Masyarakat yang paling tinggi tingkat industrialisasinya, baik kapitalis maupun komunis, adalah masyarakat di mana

${ }^{20}$ Q.S. Ar-Ra'd ayat 11.

${ }^{21}$ M. Munir dan Wahyu Ilaihi, Manajemen Dakwah (Jakarta: Prenada Media, 2006), p. 253. Untuk lebih jelas tentang perubahan sosial, baca Joseph S. Roucek dan Roland L. Warrin, Pengantar Sosiologi (Jakarta: Bina Aksara, tt.), p. 346. Lihat juga Paul B. Horton dan Chester L. Hunt, Sosiologi, (Jakarta: Erlangga, 1999), hlm. 244. Bandingkan juga dengan Jalaluddin Rakhmat, Rekayasa Sosial; Reformasi atau Revolusi (Bandung: Remaja Rosdakarya, 1999), p. 45.

${ }^{22}$ Samsul Munir Amin, Ilmu Dakwah, pp. 222-3.

23 Ibid., p. 223-4. 
pola-pola universalistis tampak menonjol dan karier terbuka untuk berbagai bakat dan kemampuan.

3. Ascription ke achievement. Demikian pula halnya achievement dan bukannya ascription, ia cenderung menjadi dasar rekrut mendalam suatu masyarakat yang terindustrialisasi sepenuhnya. Perubahan karena industrialisasi adalah perubahan dari sistem penghargaan karena prestise ke sistem penghargaan karena prestasi.

4. Diffuseness ke specific. Yang dimaksud adalah perubahan dari hubunganhubungan sosial yang memiliki ruang lingkup luas dan serba meliputi, ke hubungan-hubungan di mana seseorang aktor atau pelaku tindakan membatasi perhatiannya mengenai orang lain pada hal-hal yang bersifat khusus dan tidak mengizinkan masuk pertimbangan-pertimbangan lain. Contoh hubungan diffuse ialah antara ayah dan anak, sedangkan contoh hubungan spesifik (specific) ialah antara guru dan murid di sekolah umum. Seorang ayah akan berperan sebagai ayah terhadap anaknya dalam segala situasi. Sedangkan seorang guru berperan sebagai guru terhadap muridnya hanya pada situasi si sekolah, di kelas, atau situasi yang menyangkut kegiatan pengajaran dan pendidikan.

Terjadinya perubahan sosial membawa dampak juga kepada proses dakwah di kalangan masyarakat. Cara pandang, cara berpikir, dan cara bertindak masyarakat berubah dengan drastis terhadap fenomena keberagaman masyarakat. Dalam hal ini, dakwah harus mampu mengimbangi perubahan sosial yang terjadi di masyarakat untuk mengarahkan kepada hal-hal yang bersifat positif.

Dari berbagai bentuk perubahan sosial yang diungkapkan di atas, justru dakwah atau $d a^{\prime} i$ perlu peduli dengan terus membaca perkembanganyang terjadi di lingkungan masyarakat. Dari hasil membaca tadi, seorang da'i harus mampu memberikan solusi yang konstruktif, yang sesuai dengan ajaran, norma, dan etika Islam yang dinamis, transformatif, kondisional. Dengan begitu, da'i dapat menggerakkan masyarakat agar bangkit dari segala bentuk keterbelakangan menuju cahaya iman dan kemajuan ilmu pengetahuan. 


\section{Problematika Dakwah}

Seiring dengan perkembangan dakwah yang semakin meluas serta gerakan organisasi dakwah yang semakin berkembang pesat, baik di masyarakat maupun di berbagai perguruan tinggi Islam, tidak lantas membuat problematika dakwah hilang dari bayang-bayang majunya pergerakan dakwah. Problematika kerapkali muncul mengiringi pergerakan dakwah tersebut. Problematika dakwah yang mengemuka pada umumnya dapat dibedakan menjadi dua macam, yakni problematika internal dan problematika eksternal. ${ }^{24}$

Problematika internal diklasifikasikan dalam dua kelompok. Pertama, kelemahan para $d a^{\prime} i$ terhadap pemahaman konsep-konsep agama sebagai substansi dakwah, metode yang dipakai serta kualitas da'i itu sendiri. Kedua, kelembagaan dakwah yang kurang profesional dalam aspek manajemen.

Adapun problematika eksternal adalah suatu keadaan yang merintangi gerakan dakwah yang datang dari faktor luar, baik struktur politik nasional maupun internasional yang mengalami interdepedensi sistem, ${ }^{25}$ maraknya ghazw al-fikr, imperialisme Barat, gerakan pemurtadan yang dilakukan para misionaris, ${ }^{26}$ maupun melajunya sains dan teknologi. Faktor-faktor inilah yang telah menggusur hampir seluruh potensi rohaniah manusia, menyisihkan dan merusak etika, moral, serta akhlak, dan seharusnya menjadi fokus dalam dakwah Islam. ${ }^{27}$

Selain problematika internal dan eksternal dalam pelaksanaan dakwah, seringkali juga ditemukan problematika lain. Pertama, permasalahan teknis. Kedua, permasalahan secara umum yang menyangkut berbagai aspek kehidupan manusia, yaitu aspek sosial budaya, ekonomi dan politik merupakan.

Kecenderungan sosial budaya yang terjadi di antaranya reifikasi, objektivikasi manusia dan manipulasi. ${ }^{28}$ Kecenderungan ekonomi berkisar kepada masalah

24 Samsul Munir Amin, Rekontruksi Pemikiran Dakwah Islam, p. 159.

25 Ibid.

${ }^{26}$ Kartika Sari, “Problematika Dakwah di Indonesia dan Upaya Menjawab Tantangan,"dalam Imam Malik, dkk., Antologi Pemikiran Dakwah Kontemporer, (Yogyakarta: Idea Press, 2011), p. 87-8.

27 Samsul Munir Amin, Ilmu Dakwah, p. 309.

28 Reifikasi yaitu kecenderungan manusia untuk menilai dan menikmati sesuatu hanya dengan ukuran-ukuran yang bersifat lahiriah semata (pragmatis), objektivikasi manusia yaitu terperangkapnya manusia dalam kerangka sistem budaya dan teknologi sehingga dirinya menjadi komponen yang sangat tergantung pada sistem tersebut, sedangkan manipulasi merupakan efek 
permodalan yang menyangkut keterbatasan sumber modal, ketenagakerjaan, di mana jumlah pengangguran semakin meningkat dikarenakan mereka tidak terlatih, sedangkan yang dibutuhkan adalah tenaga kerja yang terlatih dan ahli. Kemudian keadilan ekonomi, di mana yang kuat dialah yang berhak berkuasa. Sedangkan kecenderungan politik, di antaranya partai-partai politik yang berbasis massa Islam belum bersatu untuk mengedepankan dakwah Islam dan lebih mengedepankan kepentingan politik masing-masing. ${ }^{29}$

Upaya untuk menjawab tantangan problematika dakwah di atas setidaknya ada dua hal yang harus terpenuhi. Pertama, humanisasi yang berarti dakwah harus memberi kontribusi terhadap nilai-nilai manusiawi dengan lingkungannya, yang pada gilirannya akan menjelmakan struktur sosiokultural yang sehat dan dinamis serta sejahtera. Kedua, liberasi yaitu serangkaian kegiatan yang dilakukan dalam rangka membebaskan manusia dari keterbelengguan berpikir, kebodohan, keterbelakangan, kemiskinan, dan nilai-nilai negatif dari struktur sosiokultural yang kacau. ${ }^{30}$

Sementara dalam konsep pemikiran yang praktis, Amin Rais menawarkan lima "Pekerjaan Rumah" yang perlu diselesaikan, agar dakwah Islam di era informasi sekarang tetap relevan, efektif, dan produktif.

Pertama, perlu ada pengkaderan yang serius untuk memproduksi juru-juru dakwah dengan pembagian kerja yang rapi. Ilmu tabligh belaka tidak cukup untuk mendukung proses dakwah, melainkan diperlukan pula berbagai pengusaan dalam ilmu-ilmu teknologi informasi yang paling mutakhir.

Kedua, setiap organisasi Islam yang berminat dalam tugas-tugas dakwah perlu membangun labolatorium dakwah (labda). Dari hasil "labda" ini akan dapat diketahui masalah-masalah rill di lapangan, agar jelas apa yang harus dilakukan.

Ketiga, proses dakwah tidak boleh lagi terbatas pada dakwah bil-lisan, tapi harus diperluas dengan dakwah bil-hal, bil-kita>bah, bil-hikmah, dan bil-iqtisa>diyah (ekonomi). Yang jelas, actions. Speak louder than word.

samping lain dari makin dipadatinya kehidupan manusia oleh teknologi. Lihat Kartika Sari, “Problematika Dakwah di Indonesia dan Upaya Menjawab Tantangan", p. 79.

${ }^{29}$ Ibid., p, 80-3.

${ }^{30}$ Ibid., p. 88. Bandingkan dengan Samsul Munir Amin, Ilmu Dakwah, p. 305-6. 
Keempat, media masa cetak dan terutama media elektronik harus dipikirkan juga. Media elektronik yang dapat menjadi wahana atau sarana dakwah perlu dimiliki oleh umat Islam.

Kelima, merebut para remaja merupakan tugas dakwah jangka panjang. Anakanak dan para remaja adalah aset yang tak ternilai. Mereka wajib diselamatkan dari pengikisan akidah yang terjadi akibat "invasi” nilai-nilai nonislami ke dalam jantung berbagai komunitas Islam. Bila anak-anak dan remaja memiliki benteng tangguh (alhususn al-hami>diyah) dalam era globalisasi dan informasi sekarang ini. ${ }^{31}$

Menghadapi objek dakwah yang berada dalam kondisi transisi, maka para $d a^{\prime} i$ harus mampu menginterpretasikan dakwah sebagai gerakan moral dan gerakan kebudayaan. Sebagaimana yang dilakukan oleh Nabi Muhammad Saw. empat belas abad yang silam, dakwah berfungsi sebagai transformator sosial budaya yang berakar pada keyakinan adanya Tuhan Yang Maha Esa dan mempunyai tujuan secara kuantitatif, dengan penciptaan masyarakat yang sadar akan perlakuannya selama ini adalah hasil dari mereduksi budaya Barat, sehingga perlu ditransformasikan ke etika Islam.

\section{E. Hakikat dan Signifikansi Dakwah}

Pada dasarnya dakwah terbagi menjadi dua kelompok besar. Pertama, sebagai aktualisasi fungsi kerisalahan; dan kedua, sebagai upaya manifestasi dari rahmat li al-'alamin. Hakikat dakwah sebagai aktualisasi fungsi kerisalahan, berarti upaya penerusan "tradisi profetis" kerasulan Muhammad sebagai pembawa risalah Islam kepada seluruh umat manusia.

Sedangkan hakikat dakwah sebagai manifestasi rahmat li al-'alamin berarti upaya menjadikan Islam sebagai sumber konsep bagi manusia di dunia ini dalam meniti kehidupannya. Keduanya merupakan sebuah kesatuan yang terpadu dan saling terkait dan ini disebabkan karena agama Islam mengandung nilai-nilai humanis teosentris yang universal bagi semua umat manusia. ${ }^{32}$

90.

${ }^{31}$ Kartika Sari, “Problematika Dakwah di Indonesia dan Upaya Menjawab Tantangan,” p. 89-

32 Samsul Munir Amin, Rekontruksi Pemikiran Dakwah Islam, p. 46-9. 
Menurut Kuntowijoyo, "tradisi profetis" ini merupakan pengkodisian situasi historis Nabi ke dalam aktualisasi kehidupan manusia. ${ }^{33}$ Dengan demikian, maka aktualisasi fungsi kerisalahan tersebut mengandung dua proses transformasi. ${ }^{34}$ Lebih dari itu, menurut Ahmad Syafi'i Ma'arif, dakwah Islam merupakan perencanaan dan penyerahan kegiatan dan operasi dakwah yang dibuat secara rasional untuk mencapai tujuan yang meliputi seluruh dimensi kemanusiaan. ${ }^{35}$

Pertama, transformasi nilai (transformation of value), yaitu proses alih nilai dari kejahiliyahan, baik yang terdapat pada agama-agama selain Islam atau keyakinan lainnya, maupun nilai-nilai yang terdapat pada paham-paham pemikiran, seperti, marxisme, idealisme, materiaisme. Maka, dakwah adalah upaya pengembangan manusia kepada tatanan budaya dan peradaban luhur yang dicitacitakan umat manusia. ${ }^{36}$

Kedua, transformasi sosial (tranformation of social). ${ }^{37}$ Salah satu kepentingan besar Islam sebagai sebuah ideologi sosial adalah bagaimana mengubah kondisi masyarakat sesuai dengan cita-cita dan visinya mengenai transformasi sosial. Semua ideologi dan filsafat sosial menghadapi suatu permasalahan pokok, yakni bagaimana mengubah masyarakat dari kondisinya yang terbelakang menuju kepada keadaan masyarakat yang lebih beradab dan humanis. ${ }^{38}$

Islam sangat memperhatikan dan berkepentingan terhadap realitas sosial, bukan untuk dipahami, tetapi juga berkehendak untuk diaktualisasikan. Jadi, tidaklah Islami jika umat Islam bersikap acuh terhadap kondisi sosial masyarakatnya, sementara mengetahui bahwa kondisi masyarakat tersebut mungkar. ${ }^{39}$ Dengan demikian dapat dipahami bahwa pada pengertian pertama, dakwah sebagai tranformasi nilai merupakan proses komunikasi dari komunikator

${ }^{33}$ Kuntowijoyo, Paradigma Islam Interpretasi untuk Aksi (Bandung: Mizan, 1991), p. 294.

${ }^{34}$ Samsul Munir Amin, Rekontruksi Pemikiran Dakwah Islam, p. 46-7.

35 Ahmad Syafi'i Ma'arif, al-Qur'an Realitas Sosial dan Limbah sejarah; Sebuah Refleksi (Bandung: Pustaka, 1995), p. 102.

${ }^{36}$ Samsul Munir Amin, Rekontruksi Pemikiran Dakwah Islam, p. 47.

37 Dakwah dalam pengertian transformasi sosial, bersifat multidimensi. Misalnya, dakwah yang dilakukan Nabi dengan membangun kembali masyarakat Arab dari masyarakat jahiliyah menjadi masyarakat islami, yang beradab dalam tatanan sosialnya, dari masyarakat yang strukturnya menginjak-injak hak asasi manusia, menjadi masyarakat yang menghargai hak asasi manusia.

${ }^{38}$ Samsul Munir Amin, Rekontruksi Pemikiran Dakwah Islam, p. 47.

${ }^{39}$ Kuntowijoyo, Paradigma Islam Interpretasi untuk Aksi, p. 337. 
terhadap komunikan dengan menyampaikan pesan sehingga terjadi perubahan perilaku. Adapun pada level sosialnya, proses transformasi nilai Islam yang intinya mengajak kepada hubungan humanisme teosentris. Karena itu, perubahanperubahan sosial masyarakat yang berlaku semestinya mengacu pada dimensi fitrah kemanusiaan dan kemasyarakatannya.

Setiap individu Muslim berkewajiban untuk menyampaikan dakwah Islam kepada orang lain menurut kemampuan masing-masing. Kewajiban inilah yang menyebabkan Islam berkembang pesat karena setiap Muslim dituntut untuk menyampaikan risalah Islam kepada segenap manusia sebagai rahmat li al-'alamin.

Agar dakwah yang dilaksanakan itu benar-benar fungsional dan mempunyai peranan transformatif, maka tugas $d a^{\prime} i$ adalah mempersiapkan diri semaksimal mungkin. Salah satunya mencari penyebab mengapa perubahan sosial dan problematika dakwah itu terjadi. Dalam konteks inilah para da'i dituntut untuk melakukan transformasi kultural dan sosial dalam masyarakat yang masih dalam era transisi. Ini menunjukkan bahwa peran dan fungsi $d a^{\prime} i$ dalam era globalisasi yang sarat industri dan informasi sedang diuji.

Adapun signifikansi dakwah Islam dalam perkembangan tata nilai masyarakat adalah mengarahkan cara pandang masyarakat kepada nilai-nilai positif, dan di dalam melakukan dakwah harus diperhatikan bagaimana kondisi sosiokultural yang sedang berlangsung pada masyarakat serta waktu dan tempat tersebut karena antara dakwah dengan relaitas sosiokultural selalu saling mempengaruhi. Di satu sisi dakwah Islamiyah mampu memberikan output (hasil dan pengaruh) terhadap lingkungannya sehingga masyarakat yang islami. Di sisi lain, dakwah Islamiyah juga dipengaruhi oleh perubahan masyarakat dalam eksistensi, corak dan gayanya, serta arah yang dituju. ${ }^{40}$

Kalau dahulu konsep dakwah lebih berfokus pada persoalan surga dan neraka serta kesalehan individual formalistik, maka menurut Samsul Munur Amin ${ }^{41}$ perlu dirumuskan kembali aktivitas dakwah agar benar-benar mempunyai peranan transformatif dan emansiparotis dengan

40 Samsul Munir Amin, Rekontruksi Pemikiran Dakwah Islam, p. 64-5.

41 Ibid., p. 226. 
1. meluaskan fokusnya pada pembebasan manusia dari pengangguran, kemiskinan, ketakutan, kebodohan, krisis moral, disparitas antara si kaya dan si miskin, dan ketersaingan. Berikan peluang kepada manusia untuk mengembangkan diri sesuai dengan bakat dan kemampuannya yang bersih dari penyakit korupsi, kolusi, dan nepotisme;

2. melakukan humanisasi terhadap kegiatan birokrasi, pasar, dan indutrialisasi; dan

3. sebelum semua dilakukan, maka seorang $d a^{\prime} i$ harus mendefinisikan diri sebagai orang yang dapat dipercaya (al-Amin) dengan kepribadian seperti yang diterangkan dalam Surah al-Muddatsir.

Dengan rumusan di atas, diharapkan dakwah dapat kembali memainkan peranan dan fungsinya dalam kehidupan yang penuh dengan nuansa-nuansa baru tersebut, sehingga kearifan ilahi dapat terwujud dalam bentuk kearifan insani. Gerakan dakwah pun harus mampu memberikan jawaban terhadap permasalahan yang timbul dalam masyarakat sebagai peran serta dalam menghadapi perubahan sosial yang terjadi di tengah-tengah kehidupan masyarakat.

Paralel dengan fungsi dan peran dakwah, para da'i pun mengemban peran yang sama dengan dakwah, yaitu untuk memulihkan keseimbangan, mengarahkan pembebasan, memberikan solusi terhadap problematika dakwah, sekaligus meletakkan pola dakwah dalam berbagai perspektif, dan mengubah kondisi masyarakat kepada arah yang lebih layak, baik secara fisik maupun rohani, serta terpenuhinya kelengkapan hidup baik sandang, pangan, dan papan melalui transformasi nilai-nilai moral dan etika Islam agar tercapainya kehidupan masyarakat yang beradab (civil society).

\section{F. Penutup}

Menyimak uraian-uraian di atas, dapat diprediksi bahwa misi dan tantangan dakwah tidaklah pernah akan semakin ringan, melainkan akan semakin berat dan hebat bahkan semakin kompleks dan melelahkan. Inilah problematika dakwah masa kini. Oleh sebab itu, semuanya harus diatur kembali dengan manajemen dakwah yang profesional dan dikelola oleh tenaga-tenaga berdedikasi tinggi, mau berkorban dan ikhlas beramal. 
Dakwah yang efektif adalah dakwah yang dapat memberikan tidak hanya sebatas keinginan masyarakat akan tetapi lebih dari itu adalah menjadi kebutuhan masyarakat. Untuk itu, khazanah objektivitas terhadap keadaan masyarakat mutlak diperlukan, yang pada kegiatan berikutnya akan diwujudkan dalam bentuk kepercayaan dakwah dalam matriks dakwah yang masing-masing mempunyai titik tekan sendiri, sehingga pada tahap pergerakan dakwah diaktualisasikan program dan rencana yang telah disusun sebagaimana kondisi objektif yang ditangkap masyarakat. Berhasil atau tidaknya dakwah yang dilakukan akan dievaluasi pada tahap akhir untuk dicari kelemahan dan sebab-sebabnya.

Mengingat potensi umat Islam yang potensial masih sangat terbatas, sementara harus mengakomodasi segenap permasalahan dan tantangan yang muncul, maka ada baiknya mencoba untuk memilih dan memilah mana yang tepat untuk diberikan skala prioritas dalam penanganannya, sehingga dana, tenaga, dan pikiran dapat lebih terarah, efektif, dan produktif dalam penggunaannya. 


\section{DAFTAR PUSTAKA}

Amin, Samsul Munir, Rekonstruksi Pemikiran Dakwah Islam, Jakarta: Amzah, 2008.

----, Ilmu Dakwah. Jakarta: Amzah, 2009.

Azra, Azyumardi, Konflik Baru Antar Peradaban; Globalisasi, Radikalisme dan Pluralitas, Jakarta: Raja Grafindo Persada, 2002.

Badruttamam, Nurul, Dakwah Kolaboratif Tarmizi Taher, Jakarta: Grafindo Khazanah Ilmu, 2005.

Efendi, Muchsin dan Faizah, Psikologi Dakwah, Jakarta: Prenada Media, 2006.

Halimi, Safrodin, Etika Dakwah dalam Perspektif Al-Qur'an, Antara Idealitas Qur'ani dan Realitas Sosial, Semarang: Wali Songo Press, 2008.

Horton, Paul B. dan Chester L. Hunt, Sosiologi, Jakarta: Erlangga, 1999.

Husaini, Murtadha, Kode Etik Mubalig Tuntunan Dakwah Secara Islam, Jakarta: Citra, 2011.

Kuntowijoyo, Paradigma Islam Interpretasi untuk Aksi, Bandung: Mizan, 1991.

Ma'arif, Ahmad Syafii, al-Qur'an Realitas Sosial dan Limbah sejarah: Sebuah Refleksi, Bandung: Pustaka, 1995.

Malik, Imam, dkk., Antologi Pemikiran Dakwah Kontemporer, Yogyakarta: Idea Press, 2011.

Munawwir, Warson, Kamus Al-Munawwir, Surabaya: Pustaka Progressif, 1997.

Munir, M. dan Wahyu Ilaihi, Manajemen Dakwah, Jakarta: Prenada Media, 2006.

Rakhmat, Jalaluddin, Rekayasa Sosial: Reformasi atau Revolusi, Bandung: Remaja Rosdakarya, 1999.

Roucek, Joseph S. dan Roland L. Warrin, Pengantar Sosiologi, Jakarta: Bina Aksara, tt.

Shihab, Alwi, Islam Inklusif, Bandung: Mizan, 1998.

Sumarta, Th., Pluralisme, Konflik dan Pendidikan Agama di Indonesia, Yogyakarta: Interfidei, 2001.

Tim Penyusun, Kamus Besar Bahasa Indonesia, Jakarta: Pusat Bahasa, 2008.

Tim Penyusun, Kamus Besar Bahasa Indonesia, versi ofline dengan mengacu pada data dari KBBI daring (edisi III) dari http://pusatbahasa.diknas.go.id/kbbi/ diakses tanggal 27 Desember 2012. 